\title{
IMPROVING THE PHYSICAL AND MECHANICAL CHARACTERISTICS OF AI- Mg ALLOYS FOR VEHICLE COLLISION PROTECTION
}

\author{
Institute of Technical Mechanics \\ of the National Academy of Sciences of Ukraine and the State Space Agency of Ukraine \\ 15 Leshko-Popel St., Dnipro 49005, Ukraine; e-mail: e-mail: vposhivalov@ gmail.com
}

The physical and mechanical properties of $\mathrm{Al}-\mathrm{Mg}$ alloys employed in shock-absorbing structural components of vehicles were studied. Specimens of $\mathrm{AMg} 6$ alloy were studied experimentally according to Standard GOST 1497-84 to determine its ultimate mechanical characteristics attainable by heating and accelerated cooling. To determine the physical and mechanical characteristics of large-size components of shock-proof structures made of this alloy and to develop industrial heat treatment processes, $300 \mathrm{~mm} \times 250 \mathrm{~mm} \times 30 \mathrm{~mm}$ specimens were used. The specimens were heated in air-filled SNV electric furnaces and cooled in hardening tanks. The specimens were loaded into a cold furnace. The furnace laboratory temperature was brought to a specified one, and the specimen temperature was measured with chromel-copel thermocouples. The specimens were hold at a specified temperature of $450{ }^{\circ} \mathrm{C}$ for 90 minutes. The cooling medium was $6{ }^{\circ} \mathrm{C}$ to $25^{\circ}$ running water and $100^{\circ}$ still boiling water.

The test results showed that this treatment increases the lateral impact strength by $(8-10) \%$ and reduces the longitudinal impact strength by $(2-4) \%$ on accelerated cooling in comparison with an annealed alloy. It was shown that accelerated cooling of $\mathrm{Al}-\mathrm{Mg}$ alloys from $450^{\circ}$ to a room temperature increases their impact strength by $(10-15) \%$ and their unit elongation while reducing their yield point by $(18-23) \%$ and keeping their ultimate strength intact. On heating to $80^{\circ}$ and air cooling, the impact strength of specimens treated by the accelerated cooling, while decreasing by $5 \%$, is $12 \%$ higher than the impact strength of annealed specimens and annealed specimens heated as indicated above.

Keywords Al-Mg alloy, physical and mechanical properties of a material, heating, cooling, annealing, shockproof structures.

1. Bogomaz G. I., Hudramovych V. S., Sobolevska M. B., Syrota S. A., Khrushch I. K., Horobets D. V., Demeshko M. F. Experimental development of energy-absorbing elements for passenger car protection in an emergency. Visnyk Dnipropetrovskoho Unoversytetu. Mekhanika. 2007. V. 2. Iss. 11. Pp. 19-28. (in Russian).

2. Kanel' G. I., Razorenov S. V., Utkin A. V., Fortov V. E. Shock-Wave Phenomena in Condensated Media. Moscow: Yanus-K, 1996. 408 pp. (in Russian).

3. Bisyk S. P. Study of the design of a protective anti-mine shield. Viiskovo-Tekhnichnyi Zbirnyk. Hetman Petro Sahaidachnyi National Army Academy. 2015. No. 12. Pp. 110-117. (in Ukrainian).

4. Boguslaev V. A., Kachan A. Ya., Kalinina N. E. et al. Aerospace Materials and Technologies: Handbook. Zaporizhzhia: Motor Sich, 2009. 351 pp. (in Russian).

5. Kuzmitskaya A. I., Zhdanov V. S., Poshivalov V. P. Effects of high-speed cooling on physical and mechanical properties of AMg6 aluminum alloy after high-temperature heating. Teh. Meh. 2016. No. 2. Pp. 128-136. (in Russian).

6. Sanin A. F., Poshyvalov V. P., Bisyk S. P., Kyzmytska O. I., Zhdanov V. S., Zahreba O. I. Making components of protective anti-mine shields from AL-MG alloys. Problems in the Coordination of the Military-Technical and the Defense-Industrial Policy in Ukraine. Prospects for the Development of Arms and Military Hardware: 5th Intrenational Scientific and Practical Conference: abstracts (Kyiv, October 11-12, 2017). Kyiv: DNU UkrINTEI, 2017. 191 pp. (in Ukrainian). 